\title{
GEOPARKS IN CULTURAL AND LANDSCAPE PRESERVATION CONTEXT
}

\author{
Dmitry Porshnov ${ }^{1}$, Juris Burlakovs ${ }^{1,2,3}$, Mait Kriipsalu ${ }^{1,3}$, Jovita Pilecka $^{4}$, Inga Grinfelde ${ }^{4}$, Yahya Jani², \\ William Hogland ${ }^{2}$ \\ ${ }^{1}$ University of Latvia, Latvia \\ ${ }^{2}$ Linnaeus University, Sweden \\ ${ }^{3}$ Estonian University of Life Sciences, Estonia \\ ${ }^{4}$ Latvia University of Life Sciences and Technologies, Latvia \\ juris@geo-it.lv
}

\begin{abstract}
Society aims to develop frames for recognizing important geological and geomorphological sites and features or landscapes within their national and even transnational boundaries. Earth heritage sites educate the general public and preserve cultural and environmental matters. New trends of sustainable development, importance of site conservation are demanding that landforms and landscapes, rocks, minerals, fossils, soils should be protected legally, as they give understanding about the evolution of Mother Earth in local and regional context to generations. The Geopark concept was developed in cooperation with UNESCO and followed a large number of requests to UNESCO from all over the world, from geological institutions and geoscientists and non-governmental organizations, and it became extremely popular and influential to preserve those geological heritage areas, nowadays still recognized only nationally or not at all. This paper aims to give comprehensive overview of existing geoparks in the Baltic Sea Region, as well as analyze aspiring geoparks and unpublished initiatives of potential geopark (Livonia and Vooremaa) eventual establishment in frames of cultural and landscape preservation context. Criteria, requirements and earlier studies are given in context. The geoparks should mainly contain cultural and educational purpose while targeting the least possible damage in preservational aspect.
\end{abstract}

Key words: geoparks, natural heritage, industrial heritage, Swedish Institute, landscape aesthetics, landscape didactics.

\section{Introduction}

The UNESCO headquarters in Paris held an important meeting on February 13, 2004 to work on 'Operational Guidelines for National Geoparks seeking UNESCO's assistance'. Then 'UNESCO Network of National Geoparks' was born (Ólafsdóttir \& Dowling, 2014; Sinnyovsky, 2014). It creates a unified platform for collaboration among experts and practitioners in order to preserve and popularize for wider audience geological heritage matters under the powers of UNESCO. Common values are shared by various participants all over the world. Strategy and best practices are shared and developed for the preservational context including the landscape and cultural issues. Sustainable preservation of the geological and geomorphological heritage has a crosspoint with preservation of industrial heritage as well where the mining regions are situated. Geological and geomorphological monuments very often have a cultural value from immemorial times as objects being treated in folklore and thus becoming cultural monuments of nationwide importance (Wójtowicz et al., 2011; Fassoulas \& Zouros, 2010; Azman et al., 2010). Since United Nations Conference on Environment and Development held in Rio de Janeiro, 1992, the Agenda of Science for Environment and Development into the 21st Century was accepted. UNESCO, the United Nations Organisation for Education, Science and Culture set two frameworks: the World Heritage Convention and bilateral cooperation through Division of Earth Science activities. World Heritage Committee identifies and monitors places to be put on the World Heritage List. Criteria are extremely strict: 'universal value areas of conservation of geological and threatened species'. Just to name a few, Grand Canyon, the Hawaii Volcanoes, Yosemite-National Park, the Aeolian Islands in Italy, Lake Baikal, the Kamchatka Volcanoes and many others (more than 800) are recognized on the World Heritage List. The World Heritage List will have up to 1500 sites (cultural plus natural). On the other hand, the Geopark concept was developed on request of geological institutions and geoscientists as well as non-governmental organizations, pinpointing the need for additional category that helps preventing and popularizing geological and geomorphological, natural and sinergical cultural values. Promoting regional sustainable development, research and training, educational values are of the paramount importance in the concept (Fassoulas et al., 2007).

Geodiversity - the one of pillars for the geopark existence and creation shall be used for scientific, educational, as well as tourism, providing precious resource and requiring efficient exploitation for production of socio-economic benefits (Ruban, 2017). Geoparks may contain ancient cultural objects as well as areas of economic and industrial activities; therefore, it is important to raise awareness of the society living there and the people coming there as of recreational and educational needs. Stakeholder 
active involvement is crucial (Brown et al., 2012). Since United Nations Conference on Environment and Development, stakeholders such as decision makers, scientists, planners, and the general public have all approved the need for comprehensive approach for saving the heritage in context of sustainable environment, economics and culture values. Holistic approach would incorporate protection of geological heritage with economic renewal and education / research promotion. It was already recognized in 1991 with Digne Declaration that was the first widely - recognised statement of the background to geoconservation. Rome International Conference on Geoconservation in 1996 and the European Association for Conservation of the Geological Heritage (ProGEO) proposed that UNESCO should create geological heritage preservation places as Geosphere Reserves. UNESCO has developed this proposal (Ólafsdóttir \& Dowling, 2014; Sinnyovsky, 2011) and new internationally recognised label 'UNESCO Geopark' was born, destined to become synonymous to environmental protection and development. The idea was to add around 20 recognized geopark areas around the world each year. According to UNESCO, today there are 140 Global Geoparks in 38 countries (UNESCO Global Geoparks, 2017).The Division of Earth Sciences of UNESCO taking initiatives together with International Union of Geological Sciences (IUGS) and authorities (governments) added the idioms of 'geotopes', 'geosites', or general geological heritage. Relationship among people and earth history is in the center of the paradygm of geoparks. Geoparks do not add additional protection status to existing areas: however, they help earth history sites or areas to be used as for sustainable economy promotion in concert with tourism and educational promotion. It gives additional input for preservation of the cultural and landscape heritage intangible values (Jones, 2018; Azman et al., 2010; Bujdosó et al., 2015).

This paper aims to give comprehensive overview of existing geoparks in the Baltic Sea Region, as well as analyze aspiring geoparks and unpublished initiatives of potential geopark (Livonia and Vooremaa) eventual establishment in frames of cultural and landscape preservation context.

\section{Existing Geoparks in the Baltic Sea Region}

Odsherred Unesco Global Geopark (Denmark)

Geological heritage of Denmark's only UNESCO Global Geopark: Odsherred, is mainly made up of glacial structures formed approx. 17,000 years ago. Three very distinct end moraines: Odsherred Arches form the core of Geopark. The complex of mentioned structures, surrounding depressions and meltwater represent a classical geomorphological example of a glacial landform that is considered unique by glaciologists and geologists all over the world (Odsherred UNESCO Global Geopark, 2017).

Rokua Unesco Global Geopark (Finland)

Rokua UNESCO Global Geopark is in Northern Finland. Geosite has several impressive bedrock sites, representing the main development stages of the Fennoscandian bedrock area. Diverse range of landscape forms formed during retreating glacier are consisting of varied mosaic of lots of geological formations, such as drumlins, hummocky moraines, terminal moraines, esker ridges, kettle holes, ancient shorelines, dunes, ravines and bogs. In addition to the geology, the areas are also connected by the prehistory of the people who followed the withdrawal of the ice sheet and sea (Rokua UNESCO Global Gerpark, 2017).

Muskauer Faltenbogen / Łuk Mużakowa Unesco Global Geopark (Germany \& Poland)

The Muskauer Faltenbogen / Łuk Mużakowa UNESCO Global Geopark is a German-Polish transnational Geopark. The main objects and most scenic are push moraines in Europe: the Muskau Arch, created during earlier Quaternary European ice ages around 340,000 years ago. Later deep valley with numerous meanders and terraces formed. The area has numerous occurrences of lignite, dunes and cold ironsulphate-mineral springs. Successions of sand, gravel, clay, and lignite beds of Tertiary age deformed by the load of the glacier may be found and seen here as well (Muskauer Faltenbogen / Łuk Mużakowa UNESCO Global Geopark, 2017).

Harz, Braunschweiger Land Unesco Global Geopark Unesco Global Geopark (Germany)

These are part of Harz Mountains composed of Palaeozoic sediments and magmatic rocks 'Braunschweiger Land' is famous for its fossil-rich sediments of the Mesozoic and Tertiary periods. Intensive mining and research happened at least 1,000 years while numerous deposits of iron ore, brown coal, salt and oil were discovered under salt diapirs. The essence is 'Golden Square Mile', consisting of the close contact between the Variscan bedrock and the precipitous Mesozoic overlying rock, with many reference outcrops providing uniqueness (Harz, Braunschweiger Land UNESCO Global Geopark UNESCO Global Geopark, 2017).

Aspiring Geoparks

In Baltic region, there are 4 geoparks that have not been registered as UNESCO Geoparks yet, but are already registered as non-profit organizations in their countries.

\section{Salpausselkä geopark}

The aspiring Salpausselkä Geopark is situated in southern Finland. Salpausselkä Geopark project was started in 2017, by Lahti University of Applied Sciences and The Geological Survey of Finland, 
assisting Metsähallitus Natural Heritage Services; in cooperation with municipalities forming the area of aspiring geopark (Asikkala, Heinola, Hollola, Kärkölä, Lahti, Padasjoki and Sysmä), with the support of EU. Ice-marginal formations with their eskers are the best - known geological features of Finland - formed of sand and gravel by glacial meltwater at the end of the last ice age 12000 - 11000 years ago they nowadays provide the City of Lahti and other municipalities of the region with good quality groundwater and, of course, geologically tells us the history of complex ice retreat.

\section{North-West Estonian Geopark}

According to Raukas (2010), North - West Estonian Geopark was formally founded in June 1, 2010 and covers Harku, Keila, Padise Nõva, Noarootsi communes as well as Paldiski town. The most monumental landform and the central geological value of the park is the North-Estonian Klint. Good preconditions for the formation of waterfalls exist in the mouths of rivers in the given area, due to intensive erossion, more than 6 meters high and around 70 meters wide Keila - Joa waterfall must be mentioned as the most important object of this type in the park. The rocks of the klint contain abundant skeletal fragments of trilobite, echinoderms, brachiopods (Raukas, 2010). Neugrund Meteorite Crater, formed in Early Cambrian some 535 million years ago, is probably one of the bestpreserved marine impact structures in the World Ocean and the only one of those where most morphological units are visible and easily accessible. Also, it must be mentioned as a very significant geological object (Suuroja \& Suuroja, 2010). Numerous Neugrund breccia boulders are found in the central and southern parts of Osmussaar island, carried here from the circular ridges of the crater by continental glacier. The most remarkable of these are megaboulders Skarvan and the Osmussaar Twins on the western coast of the island (Raukas, 2010). The biggest erratic boulder in the entire North European glaciation area, called Toodrikivi (volume over 1000 cubic meters) rests on the seabed near the Osmusaare isle (Raukas, 2010). Additionally, this area is interesting from the historical point of view due to its reach military history. The islands of Pakri were used as a practice bombing range of the Soviet army, Pakri Peninsula had the strongest concentration of the military units of the former Soviet Union in Estonia, where the nuclear reactors of the Submarine Training Centre, two nuclear missile bases and military harbours were located (Raukas, 2010). Signs of any activity of this geopark today were not found during the research.

Saarte geopark

Aspiring Saarte geopark is located in western Estonia on Saaremaa Island and surrounding smaller islets. The main geological value here is
Kaali meteorite crater: one of the most important places of morphogenetic interest in Europe (Raukas \& Stankowski, 2010). This object consists of the main crater surrounded by eight secondary craters forrmed as the result of a small meteorite shower. This meteorite shower is one of very rare cosmic catastrophes of this magnitude that took place in Europe in historical time (Raukas \& Stankowski, 2010). Limestone cliffs of Gotland-West Estonian Klint, reach in fossils representing the biota of the Paleobaltic sea during the Sillurian period is another significant geological value of aspiring geopark (Märss \& Soesoo, 2007). The most magnifient glacial landform here is the West - Saaremaa Upland - a huge end moraine height, composed mainly of till and rising 20 - 35 metres above surroundings (Raukas, 2010). The island has a rich flora and fauna and numerous architectural monuments such as medieval churches and Kuressaare Castle. The first try to get membership of the European Geopark Network and therefore also of Global Geopark Network was made by Saarte geopark at the end of 2013. In July 2014 a 2 - member delegation from the European Geopark Network and Global Geopark Network visited Saarte Geopark. Delegation got familiarized with the Saarte Geopark during their visit that lasted 3 days, application was differed and no information about the way foreward was found during the research.

Northern Vidzeme Geopark

Northern Vidzeme Geopark is founded as a nonprofit organization in 2009, development of geopark in the territory of Burtnieki, Mazsalaca, Nauksheni and Rujiena counties and joining the UNESCO Geopark program was defined as the main aim of organization. The main geological values justify the formation of geopark: there are Devonian sandstone outcrops, cliffs and caves. Characteristic glacial relief forms, erratic boulders as well as a unique testimony of ice age, such as the largest settlement in Northern Europe must be mentioned as other valuable objects of aspiring geopark. Geopark is taking part in some local activities, while no information was found about attempts to submit an application to join Global Geoparks Network.

Initially there were strong ideas about creating Livonia Geopark (Figure 1), a cross-border EstonianLatvian geopark with geotourism attractions: spectacular Devonian sandstone outcrops on river banks (incl. geoheritage sites in the Gauja national park), large mire areas along the Latvian - Estonian border. In an area of this prospective Livonia geopark operates the Northern Vidzeme Geopark (at present it is engaged only in some local activities).

Vooremaa Geopark, Eastern Estonia

A prospective Vooremaa Geopark (Figure 1) (by now the local parish authorities have agreed to 


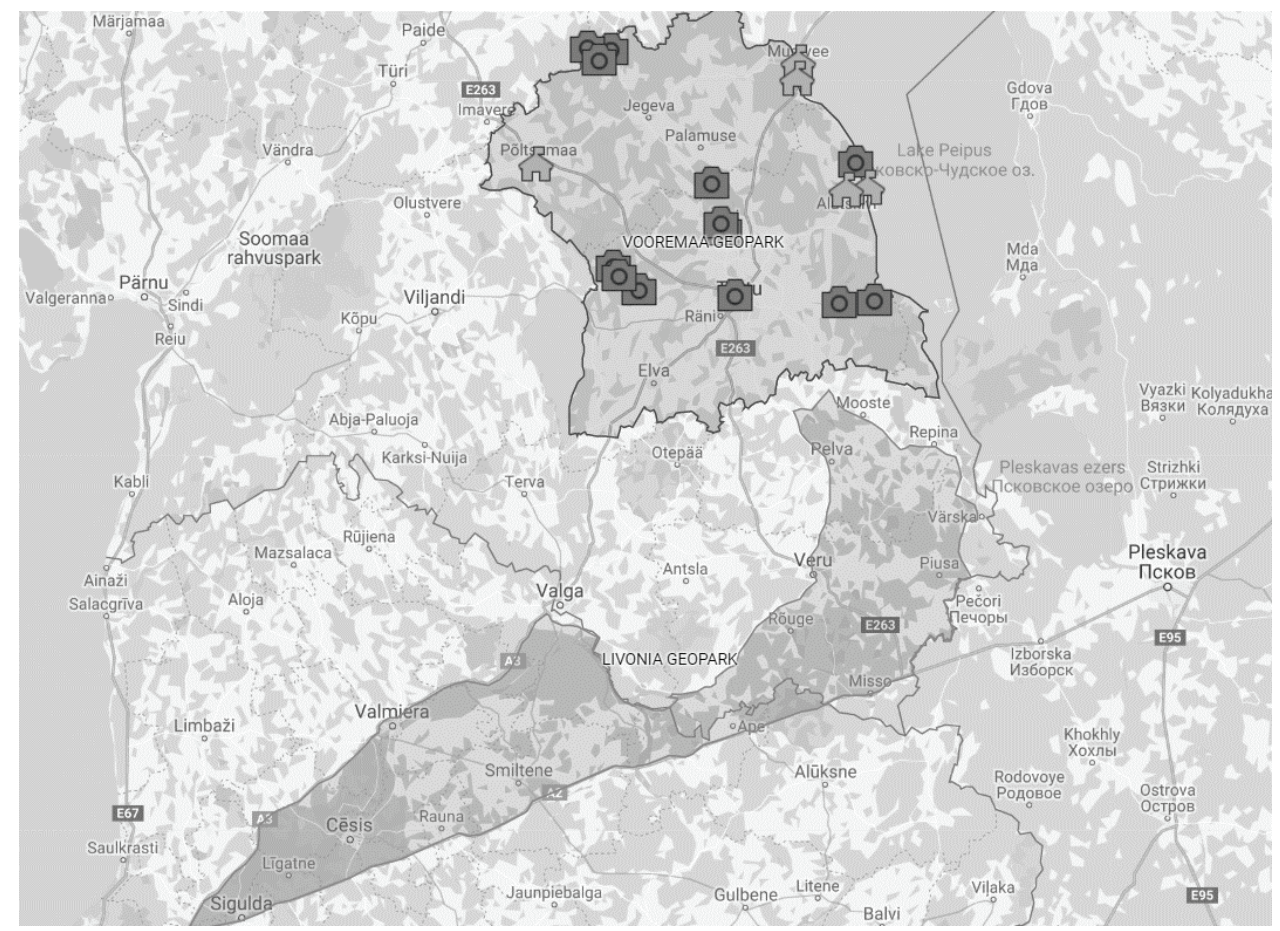

Figure 1. Geographical distribution of Vooremaa and Livonia perspective geoparks and marked geosites (author courtesy on base map of GOOGLE).

establish the Vooremaa geopark in the territory of Tartu and Jõgeva counties in February 2015). Main geotourism attractions of the Vooremaa geopark are: large mires (Endla, Alam-Pedja, Emajõe-Suursoo) of various genesis and on different development stages adjacent to the Vooremaa drumlin field; settlements of Russian Old Believers along the coast of Lake Peipsi (Starover, 2019). The Ice Age Centre at Äksi (Ice Age Centre, 2019) could be used as a headquarter for the Vooremaa Geopark. The local community leaders of Tartu and Jõgeva counties have recently agreed upon establishing the Vooremaa geopark by Spring 2016. Geologist Heikki Bauert introduced the Geopark idea in Jõgeva and Tartu counties, and Aivar Soop, the Rural Municipality Mayor, develops and leads the initiative. According to the plan, the Geopark will be created across Jõgeva and Tartu counties (Loomisel olev geopark, 2019).

'Terra Kukkersiana' geopark, northeastern Estonia could be planned as a prospective Kukersite Geopark (no public activities yet). It would be established in the Ida - Virumaa county, Northeastern Estonia. Main geotourism attractions should be kukersite oil shale (geology, mining, utilization) field sites (underground museum and water attractions in flooded mines are already opened for recreation); the North Estonian Klint - exposing Lower Cambrian to Middle Ordovician siliclastic to carbonate successions; Kuremäe Convent; Narva Castle (Narva museum, 2019) and other cultural and geo - objects.

\section{Results and Discussion}

Criteria and requirements

According to Global Geoparks Network (2014), Geopark is an area that has clearly defined boundaries and is large enough to promote sustainable economic and cultural development of the local community. The general focus of the geopark concept is the geological heritage and geodiversity, presence of impressive and internationally significant geological objects, important from the point of view of science, rarity, education and/or aesthetics, is essential for the establishment of the geopark (Azman et al., 2010) while the presence of such kind of objects alone is not enough. The establishment of a Geopark should be developed through a bottom-up process coming from a local community and local political leaders. Furthermore, political support must include the provision of necessary financial resources (Bujdosó et al., 2015). The Geopark should have professional management structures and be able to deliver policy and action for sustainable development across the territory where it is located, that is one of its main strategic objectives. The aim of the Geopark is to improve living condition of local population and quality of the surrounding environment (Azman et $a l ., 2010)$. Very important objective of geopark is to strengthen identification of the population with their area and to stimulate the 'pride of place', which in turn produces strong local support for the protection of geological heritage. Educational function of Geopark 
as well is of very high significance, it must provide and organize support for the communication of geoscientific knowledge to the general public through establishment of museums, educational centers, trails, publishing of popular literature, maps, providing modern communication media, etc. (Ólafsdóttir \& Dowling, 2014). Geopark is not a specific category of protected area or landscape, branding of area as Geopark does not affect the legal status of the land, however, the authorities responsible for the Geopark must ensure enough protection of included geological values in accordance with local traditions and legislative obligations (Fassoulas et al., 2007).

Geoparks under the assistance of UNESCO shall incorporate multiple things such as: 1) preserve geological heritage (conservation) for future generations; 2) ensure sustainable tourism; 3) educate broader audience and promote research.

As we described above - an intention and options for creating several new geoparks (aspiring and perspective) in the Baltic Sea Region in the context of geological landscape, culture, mining industry development, aesthetics is higly topical. Moreover, they will provide the socio-economic development perspectives and didactics tool for landscape learning.

World Heritage Convention and the Man and Biosphere (MAB) Reserve programme must be respected to be complementary within IUGS-IGUUNESCO Task Force 'GEOSEE'. It must have well-defined limits that have a large enough surface also for local economic development. It may not be solely of geological-palaeontological significance but also include cultural, archaeological, historical and ecological values (Wójtowicz et al., 2011; Fassoulas \& Zouros, 2010; Azman et al., 2010). So in fact it means that Geopark itself has to provide sustainable development goals for local (regional) communities and on top serve as education on the environment, research training in various disciplines of the Earth Sciences, supplement natural environment and sustainable development policies.

\section{Conclusions}

Geopark has several main tasks to fulfill when organized and approved: preserve geological heritage (conservation), educate broad public on landscape aesthetics (landscape educational didactics) and ensure sustainable development (socioeconomic and tourism aspects). In this paper, we talk about aspiring geoparks that have closest intentions and opportunities to become geoparks in foreseeable future as well as perspective ones that still are only in conceptual ideas not discussed in broader public. However, as we see from regional planning documents about infrastructure plans in far future, very often good ideas are forgotten and not implemented. Therefore, it is important to raise up the scientific and public audiences with conceptual frames of forgotten issues. The main recommendations are that 1) geoparks must be strongly incorporated in strategic documents and affirmed in UNESCO and GEOSEE; 2) this area should have distinct borders in nature with concrete defined properties of geological, landscape, cultural significance; 3) terrains and landscape units should be complementary - it may not be defined as a geopark if only separate geosites characteristics (e.g., paleontological, geomorphological or cultural specified etc.) are relevant - with that said it must have a complex uniqueness that is easy to be explained for broader public; 4) an action plan for business, education and implementation in other strategic documents should exist. This must provide additional supplementary income (tangible and/ or untangible) for the local population and attract private equity in future.

\section{Acknowledgements}

This study was supported by the Swedish Institute sponsored LASUWAMA initiative. Authors acknowledge Interreg South Baltic project 'Reviving Baltic Resilience', 'Svēte River Revitalization Plan Development and Recommendations Preparing for River Coastal Areas Management' (Latvia - Lithuania transboundary cooperation programme 2014-2020 No. LLI-291 'Enchangement of Green Infrastructure in the Landscape of Lowland Rivers' (ENGRAVE)) and Geo IT Ltd. on experience and knowledge exchange.

\section{References}

1. Azman, N., Halim, S.A., Liu, O.P., Saidin, S., \& Komoo, I. (2010). Public Education in Heritage Conservation for Geopark Community. Procedia - Social and Behavioral Sciences, 7, 504-511. DOI: 10.1016/j.sbspro.2010.10.068.

2. Brown, E.J., Prosser, C.D., \& Stevenson, N.M. (2012). Geodiversity, conservation and climate change: key principles for adaptation. Scottish Geographical Journal, 128 (3-4), 234-239. DOI: 10.1080/14702541.2012.725859.

3. Bujdosó, Z., Dávid, L., Wéber, Z., \& Tenk, A. (2015). Utilization of Geoheritage in Tourism Development. Procedia - Social and Behavioral Sciences, 188, 316-324. DOI: 10.1016/j.sbspro.2015.03.400. 
4. Fassoulas, C., Patzak, M., Zouros, N., \& McKeever, P. (2007). European and global - UNESCO networks of geoparks: Management of geological heritage and local development. $6^{\text {th }}$ International Symposium on Eastern Mediterranean Geology. Amman 2-5 April, 2007, Abstract volume (pp. 4).

5. Fassoulas, C., \& Zouros, N. (2010). Evaluating the influence of Greek geoparks to the local communities. Bulletin of the Geological Society of Greece.43 (2), 896-906. DOI: 10.12681/bgsg.11255.

6. Global Geoparks Network (2014). Guidelines and criteria for national geoparks seeking UNESCO's assistance to join the Global Geoparks Network (GGN).

7. Ice Age Centre (2019). About Ice Age Centre at Äksi. Retrieved February 24, 2019, from http://jaaaeg.ee/ en/jaaaja-keskusest/.

8. Jones, C. (2008). History of Geoparks. Geological Society, London, Special Publications, 300, $273-277$. DOI: $10.1144 / \mathrm{SP} 300.21$.

9. Loomisel olev geopark (2019). Geopark. Retrieved February 20, 2019, from http://jaaaeg.ee/geopark/en/ geopark-2/.

10. Märss, T., Soesoo, A., \& Nestor, H. (2007). Silurian cliffs on Saaremaa island. MTÜ GEOGuide Baltoscandia. Tallinn, $34 \mathrm{pp}$.

11. Narva museum (2019). Narva Castle. Retrieved February 20, 2019, from http://www.narvamuuseum.ee/ site/en/.

12. Raukas, A. (2010) Estonian geoparks. GEOLOGI, 62, pp. 202-207.

13. Raukas, A., \& Stankowski, W. (2010). The Kaali crater field and other geosites of Saaremaa Island (Estonia): the perspectives for a geopark. Geologos, 16(1), pp. 59-68. DOI: 10.2478/v10118-010-0004-z.

14. Ruban, D.A. (2017). Geodiversity as a precious national resource: A note on the role of geoparks. Resources Policy, 53, pp. 103-108. DOI: 10.1016/j.resourpol.2017.06.007.

15. Sinnyovsky, D. (2014). Management and protection of the geodiversity. National Conference with international participation 'Geosciences 2014'. Proceedings of International Conference, Bulgarian Geological Society (pp. 117-118).

16. Sinnyovsky, D. (2011). Geopark Belogradchik rocks - priority of the Bulgarian geoconservation. In: Proc. International Multidisciplinary Scientific GeoConference SGEM 2011. Vol. III, Proc. International Multidisciplinary Scientific GeoConference SGEM 2011 (pp. 389-396).

17. Starover. (2019). Russian Old Believers in Estonia. Retrieved February 24, 2019, from http://www. starover.ee/history.html.

18. Suuroja, K., \& Suuroja, S. (2010). The Neugrund meteorite crater on the seafloor of the Gulf of Finland, Estonia. Baltica, 23(1), 47-58.

19. UNESCO (2017). Harz, Braunschweiger Land Unesco Global Geopark Unesco Global Geopark(Germany). Retrieved February 22, 2019, from http://www.unesco.org/new/en/natural-sciences/environment/earthsciences/unesco-global-geoparks/list-of-unesco-global-geoparks/germany/harz-braunschweiger-land/.

20. UNESCO (2017). Muskauer Faltenbogen / Łuk Mużakowa UNESCO Global Geopark (Germany \& Poland). Retrieved February 21, 2019, from http://www.unesco.org/new/en/natural-sciences/environment/ earth-sciences/unesco-global-geoparks/list-of-unesco-global-geoparks/germanypoland/muskauerfaltenbogenluk-muzakowa/.

21. UNESCO (2017). Odsherred UNESCO Global Geopark (Denmark). Retrieved February 23, 2019, from http://www.unesco.org/new/en/natural-sciences/environment/earth-sciences/unesco-global-geoparks/listof-unesco-global-geoparks/denmark/odsherred/.

22. UNESCO (2017). Rokua UNESCO Global Geopark (Finland). Retrieved February 23, 2019, from http:// www.unesco.org/new/en/natural-sciences/environment/earth-sciences/unesco-global-geoparks/list-ofunesco-global-geoparks/finland/rokua/.

23. UNESCO (2017). UNESCO Global Geoparks. Retrieved February 23, 2019, from http://www.unesco.org/ new/en/natural-sciences/environment/earth-sciences/unesco-global-geoparks/.

24. Wójtowicz, B., Strachowka, R., \& Strzyz, M. (2011). The perspectives of the development of tourism in the areas of geoparks in Poland. Procedia - Social and Behavioral Sciences, 19, 150-157. DOI: 10.1016/j. sbspro.2011.05.118.

25. Ólafsdóttir, R., \& Dowling, R. (2014). Geotourism and Geoparks - A Tool for Geoconservation and Rural Development in Vulnerable Environments: A Case Study from Iceland. Geoheritage, 6 (1), 71-87. DOI: 10.1007/s12371-013-0095-3. 